\title{
Efektifitas Peran Orang Tua Terhadap Keberhasilan Pendidikan Keagamaan Anak
}

\author{
Muzdalifah \\ STAIN Kudus, Jawa Tengah, Indonesia \\ muzdakudus@gmail.com
}

\begin{abstract}
Abstrak
Anak merupakan amanah yang diberikan Allah kepada orang tua yang harus dipertanggungkawabkan di akhirat nanti. Islam mengharuskan orang tua tua mendidik anakanaknya beribadah kepada Allah sejak dini. Tulisan ini bertujuan memberikan pemahaman tentang pentingnya peran orang tua dalam memberikan pendidikan agama Islam sebagai pembentuk karakter Islami dan sebagai pencegah perilaku kenakalan anak dan remaja. Dalam prosesnya, keteladanan sebagai metode dalam dalam memberikan pendidikan agama Islam adalah metode paling tepat dalam membentuk akhlak anak.
\end{abstract}

Kata Kunci: Efektifitas, Orang Tua, Pendidikan Keagamaan Anak

\begin{abstract}
Children are a mandate given by God to parents who must be accounted for in the hereafter. Islam requires parents to educate their children to worship God from an early age. This paper aims to provide an understanding of the importance of the role of parents in providing Islamic religious education as a form of Islamic character and as a deterrent delinquency behaviour to children and teenagers. In the process, exemplary as a method of providing Islamic religious education is the most appropriate method in the preparation of children's morals.
\end{abstract}

Keywords: Effectiveness, Parents, Children's Religious Education 


\section{A. Pendahuluan}

Hasil laporan dari Kapolda Jabar Irjen Agung Budi Maryoto pada tanggal 22 September 2017 bahwa terdapat kasus yang memprihatinkan yaitu duel ala gladiator dan menewaskan Hilraius Chirstian Event Raharjo (15) di Kota Bogor . Hanya sekedar ingin unjuk keberanian, tiga anak baru gede (ABG) di Bekasi nekat membacok seorang pelajar SMPN 4 Cikarang Barat kabupaten Bekasi yang sedang menyeberang Jalan Raya Fatahillah, pada tanggal 14 Nopember 2017.

Menurut BKKBN diperoleh data bahwa sedikitnya 30\% siswa SMP dan SMA di Indonesia sudah melakukan seks bebas secara aktif. Selain itu, sebanyak $12.9 \%$ remaja pada usia 13-17 tahun mengalami hamil di luar nikah (Pikiran Rakyat, edisi 30 Juli 2007). Sedangkan perilaku negatif remaja terlihat dari data yang dicatat oleh BKKBN mengenai tingkat aborsi di Indonesia yaitu sekitar 2.4 juta jiwa per tahun dan sekitar 700 ribu diantaranya dilakukan oleh para remaja (BKKBN, 2007).

Penelitian Umuri, dan Fatimah (2014) Dari hasil penelitian tersebut peneliti menyimpulkan bahwa faktorfaktor penyebab kenakalan remaja yang dominan di Desa Kemadang, Kecamatan Wonosari Kabupaten Gunungkidul antara lain 1) Faktor-faktor di dalam diri anak itu sendiri yaitu, lemahnya pertahanan diri pada remaja itu sendiri karena masih terpengaruh oleh ajakan teman yang tidak baik. .2) Faktor yang kedua adalah teman sebaya di lingkungan masyarakat atau teman bermain. Remaja desa Kemadang lebih suka berkumpul dengan teman-teman bermain, dan sebagian waktunya dihabiskan untuk berkumpul dengan temannya dari pada dengan keluargannya di rumah. Temannya tersebut tidak semuannya berkelakuan baik, ada yang suka minum-minuman keras, merokok, seks bebas. Dan remaja yang lemah keimanan dan pertahanan dirinya akan ikut-ikutan dengan sikap teman sebaya yang menyimpang. 3) Faktor-faktor yang berasal di sekolah, disebabkan oleh teman di sekolah. Beberapa anak ada yang suka bolos sekolah, boloh ekstrakurikuler dan juga merokok di kantin saat jam istirahat. Kondisi seperti itu dapat berpengaruh pada anak-anak yang lain. 
Anak yang tadinya baik menjadi nakal karena dipengaruhi oleh temannya.

Kasus kenakalan remaja ini merupakan dampak dari kebijakan Menteri Pendidikan Nasional yang mnegesampingkan pendidikan moral dimana mata pelajaran Pendidikan Agama Islam tidak di -UAN kan. Ini mengakibatkan tidak mendukungnya aspek pembinaan mental siswa dan kebikan ini hanya membentuk manusia intelk yang semata-mata mengandalkan kecerdasan semata dengan standar nilai memenuhi standar nasional. Aspek moralitas yang hakiki sangat menentukan sumber daya manusia yang berkualitas diabaikan, padahal aspek ini menentukan kesuksesan pembangunan negara Baldatun Tayyibatun Wa Rabbun Ghafur yang diridai Allah SWT ( Haedari 2010, 273).

Kebijakan pemerintah yang hanya menekankan aspek kognitif dan mengabaikan aspek pembentukan moralitas siswa dalam pendidikan ini sebagai salah satu penyebab krisis moral yang melanda bangsa ini sebagaimana yang dikatakan oleh (Sukring 2013, 160) bahwa penyebab krisis moral adalah :

1. Adanya penyimpangan pemikiran dalam sejarah pemikiran manusia yang mneyebabkan paradox antar nilai, misalnya etika dan estetika.

2. Hilangnya model kepribadian yang integral, yang memadukan kesalihan dengan kesuksesan, kebaikan dengan kekuatan dan seterusnya.

3. Munculnya antagonism dalam pendidikan.

4. Lemahnya peranan lembaga sosial yang menjadi basis pendidikan moral.

Selain sekolah sebagai lembaga pendidikan formal yang diharapakan membentuk moralitas siswa, maka keluarga dengan peran orang tua sangat penting dalam membentuk moral atauk akhlak anak. Melalui keluarga, orang tua berperan memberikan pendidikan agama Islam yang berisi nilai-nilai luhur yang membentuk moral atau akhlak anak.

Dari pemaparan diatas penulis ingin menyampaikan bahwa peran orang tua dalam memberikan pendidikan agama Islam dalam membentuk moral atau akhlak anak adalah sangat penting. 
Efektifitas Peran Orang Tua Terhadap Keberhasilan Pendidikan ...

\section{B. Pembahasan}

\section{Fungsi Keluarga}

Anak adalah amanah, anak adalah anugerah dari Sang Pencipta. Orang tua bertanggung jawab secara moral kepada Sang Pencipta, terutama dalam hal mendidiknya. Kesungguhan orang tua dalam mendidik anak merupakan langkah awal keberhasilan orang tua dalam membina rumah tangga dan keluarganya, terlebih apabila anak menutut perintah orang tua, mengerti akan tugasnya dan menurut perintah agama. perilaku yang ditunjukkan akan menjadi indicator keberhasilan orang tua dalam mendidik anaknya (Afandi, 2011 dalam Arif 2015, 91).

Keluarga menurut Koerner dan Fitzpatrick (2004) dapat ditinjau berdasarkan tiga sudut pandang, yaitu definisi structural, definisi fungsional dan definisi intersaksional. Definisi structural yaitu bahwa keluarga sebagai asal usul, wahana melahirkan anak dan keluarga batih. Definisi fungsional adalah adanya penekanan pada berfungsinya tugas-tugas dan fungsi psikososial yang mencakup perawatan, sosialisasi anak, dukungan emosi dan materi dan pemenuhan peran-peran tertentu. Definisi transaksional yang mengembangkan keintiman melalui perilkau-perilkau yang memunculkan identitas sebagai keluarga yang berupa ikatan emosi , pengalaman historis maupun cita-cita masa depan (Sri Lestari 2012, 5)

Keluarga adalah satu-satunya sistem sosial yang diterima oleh semua masyarakat, baik yang agamis maupun non agamis yang memiliki peran, posisi dan kedudukan yang bermacam-macam di masyarakat. Keluarga merupakan lingkungan pertama bagi anak untuk tumbuh dan berkembang serta menjadi pondasi pendidikan yang mementukan pendidikan selanjutnya. Lewat pendidikan keluarga ini akan tumbuh masyarakat maju, muncul peradaban modern dan perkembangan-perkembangan lainnya, termasuk karakter manusia (Marzuki 2015, 66).

Menurut Berns (2004) keluarga memiliki lima fungsi dasar, yaitu: a) Reproduksi; Memiliki tugas untuk mempertahankan populasi yang ada dalam masyarakat. b) Sosialisasi atau edukasi; Menjadi sarana untuk transmisinilai, kenyakinan, sikap, pengetahuan 
dan ketrampilan dan teknik dari generasi sebelumnya kepada generasi yang lebih muda. c) Penugasan peran sosial; Memberikan identitas kepada para anggotanya seperti ras, etnik, religi, sosial ekonomi dan peran gender. d) Dukungan ekonomi; Menyediakan tempat berlindung, makanan dan jaminan kehidupan. e) Dukungan emosi dan pemeliharaan; Memberikan pengalaman interaksi sosial yang pertama bagi anak yang bersifat mendalam, mengasuh, berdaya tahan sehingga memberikan rasa aman (Sri Lestari, 2012, 16-17) .

Sesuai dengan peran dan fungsi keluarga dalam melakukan tugas sebagai pendidik, maka Allah dan Rasulullah juga memberikan petunjuk tentang syarat-syarat untuk mewujudkan keluarga yang kukuh dan sehat. Diantaranya yang terdapat dalam Alquran adalah sebagai berikut : Pertama, Larangan menikah dengan wanita yang memiliki hubungan darah dan kekerabatan tertentu. Seperti dijelaskan dalam Alquran surat Annisa' ayat 22-23. Larangan ini berpengaruh ada daya tahan fisik dan mental pada keturunan yang dilahirkannya. Bukti dan hasil penelitian dokter telah membuktikan bahwa unsure genetika yang berasal dari keluarga dekat akan mneyebabkan keluarga tersebut menjadi idiot, kurang cerdas dan . akibat ini justru mengkhawatirkan akan terjadi ketidakharmonisan keluarga yang berujung pada perceraian.

Kedua, Larangan menikah dengan orang yang berbeda agama. Larangan ini ada hubungannnya dengan masalah pendidikan anak. Jika seorang anak dilahirkan dari pasangan beda agama akan menimbulkan kebingungan pada si anak tentang agama apa yang dianut anak. Selain itu dalam hal pendapat tentang harta warisan dan masalah hukum-hukum lainnya akan menimbulkan kebingungan tentang hukum agama mana yang akan diikuti.

Ketiga, Larangan menikah dengan orang yang berzina. Larangan ini berdasarkan pada pertimbangan yang sangat luas. Wanita dan pria yang berzina akan dikhawatirkan akan membawa penyakit menular yang dapat mengakibatkan pada kecacatan fisik dan mental anak. Wanita yang mengandung anak hasil zina berada dalam suasana stress akan berpengaruh pada nak yang dikandungnya . ketika anak bertambah besar dan dewasa akan hilang 
rasa bangga dan hormat pada ibunya, sehingga tidak menguntungkan bagi pembinaan mental dan kepribadian anak (Nata 2015, 215-217)

Di dalam keluarga anak -anak menjalani proses tumbuh dan berkembang dalam suatu perkembangan dan merupakan jalur bagi peningkatan pengethauan dan informasi, penguasaan ketrampilan dan kompetensi, dukungan emosi dan pengaruh lain sejak dini. Hubungan dengan kualitas baik akan berpengaruh positif pada perkembangan, misalnya penyesuaian, kesejahteran, perilaku prososial dan transmisi nilai ,sebaliknya hubungan dengan kualitas buruk akan berakibat malasuai, masalah perilaku atau psikopatologi pada diri anak.

Penerimaan dan penolakan orang tua membentuk dimensi kehangatan dalam pengasuhan, yaitu suatu kualitas ikatan afeksi antara orang tua dan anak (Rohner, Khaleque \& Cournoyer, 2009). dimensi kehangat merupakan suatu rentang yang kontinum, yang satu sisi ditandai dengan penerimaan dengan berbagai perasaan dan perilkau yang menunjukka kehangatan, afeksi, kepedulian, kenyamanan, perhatian dan perawatan, dukungan dan cinta. di sisi lain ditandai oleh penolakan yang mencakup ketiadaan atau penarikan berbagai perasaan atau perilaku yang menyakitkan secara fisik maupun psikologis seperti memaki, tidak menghargai, penelantaran, tak acuh dan penyiksaan (Sri Lestari 2012, 16-17).

\section{Karakter Keluarga}

Karakter anak yang perlu dikembangkan sejak usia dini adalah karakter yang permanen dan tahan lama, yang diyakini berlaku bagi manusia secara universal dan bersifat absolute( bukan bersifat relatif), yang bersumber dari Alquran dan hadis.

Karakter dalam perspektif Islam adalah akhlak. Akhlak adalah nilai pemikiran yang telah menjadi sikapmental yang mengakar dalam jiwa, lalu tampak dalam bentuk tindakan yang berlaku tetap, natural dan reflek. Akhlak merupakan pondasi kokoh bagi terciptanya hubungan baik antara hamba dengan Allah SWT dan hubungan dengan sesama.akhlak mulia (akhlakul karimah) tidak lahir begitu saja sebagai kodrat manusia atau terjadi secara tiba-tiba. Akan tetapi membutuhkan proses panjang serta manifestasi seumur hidup melalui pembelajaran atau pendidikan akhlak secara 
sistematis bersifat mneyeluruh.Akhlak mulia yang dikontrol oleh nilai-nilai agama slam dapat membuat seorang muslim ammapu mnejalankan tiga hal, yaitu berinterksi dengan Tuhannya, berinteraksi dengan diri sendiri damn berinteraksi dengan orangorang. Posisi akhlak dalam Islam diibaratkan sebagai pondasi yang melandasi konstruksi bangunan yang bernama kesuksesan dunia dan akhirat bagis setiap manusia sebagai hamba Allah (Sukring 2013, 174).

Tujuan pendidikan adalah membentuk manusia berkualitas secara lahiriyah dan batiniyah. Secara lahiriyah pedidikan menjadikan manusia bermanfaat bagi dirinya dan orang lain serta dapat menentukan arah hidupnya ke depan. Sedangkan secara batiniah pendidikan diharapkan dapat membentuk jiwa-jiwa berbudi, tahu tata karma, sopan santun dan etika dalam setiap gerak hidupnya baik secara personal ma upun kolektif. Hal ini mnegandung arti bahwa pendidikan akan membawa perubahan pada setiap orang sesuai dengan kata aturan (Sukring 2013, 162).

Menurut Stark dan Glock (1968), ada lima unsur yang dapat mengembangkan manusia menjadi religious. Yaitu, kenyakinan agama, ibadat, pengetahuan agama, dan konsekuensi dari keempat unsur tersebut. Kenyakinan agama adalah kepercayaan atas doktrin ketuhanan, sperti percaya terhadap adanya Tuhan, malaikat, akhirat .

Agama dan moral adalah satu di antara lima aspek lingkup perkembangan yang harus diberikan kepada anak usia dini. Dalam agama terkandung nilai-nilai moral, etik dan pedoman hidup sehat yang universal dan abadi sifatnya. Orang tua mempunyyai tanggungjawab terhadap tumbuh kembang anak, agar bila dewasa kelak berilmu dan beriman. Maksud dan tujuan pendidikan agama pada usia dini relevan dengan Hadis Nabi yang diriwayatkan oleh Bukhari dan Muslim, yang artinya" setiap kamu adalah penanggungjawab yang akan dimintai pertanggunngjawabannya atas apa yang telah dipercayakan kepadanya, dan akan dimintai pertangungjawaban atasnya. Seorang ayah bertangungjawab atas seseorang ibu bertanggung jawab atas harta dan anak suaminya dan akan dimintai pertanggungjawaban atasnya" (Arif 2015, 87). 


\section{Metode Pendidikan Karakter}

Dalam konteks pendidikan Islam, karakter atau akhlak yang ditanamkan ke anak harus berlandaskan pada dua dimensi kehidupan yaitu dimensi ke-atuhanan dan dimensi kemanusian. Dimensi ke-Tuhanan yang disebur rabbaniyah akan melahirkan nilai-nilai keagamaan yang mendasar bagi manusia seperti iman, Islam, ihsan, taqwa, ikhlas, tawakkal, syukur dan sabar. Sedangkan dimensi kemanusiaan melahirkan akhlakul karimah yang tercermin dalam perilaku sehari-hari, seperti persaudaraan, persamaan, keadilan, baik sangka rendah hati, tepat janji, lapang dada, dapat dipercaya, perwira, hemat, dermawan dan sebagainya. Jadi kedua dimensi ini jika dikembangkan maka akan terbentuk manusia yang memiliki rasa ketakwaan kepada Allah SWT dan rasa kemanusiaan sesama manusia (Mutmainnah 2013, 75-76).

Terkait dengan pembentukan karakter, penulis ingin memaparkan tentang metode pendidikan karakter yang dirangkum oleh mutmainnah dari berbagai pendapat tokoh pendidikan karakter antara lain :

\section{a. Metode Knowing the good (mengetahui kebaikan)}

Untuk melakukan kebaikan seorang anak dikenalkan nilainilai kebaikan, pengenalan tentang kebaikan yang mendalam akan mnumbuhkan sebuah pemahaman, sehingga dapat merespon kebaikan setelah anak melihat penerapan kebaikan yang ada disekitarnya, mereka akan merespon kebaikan dengan menghubungkan fenomena yang terjadi dan mensintesa dengan mengeneralisasikan pemahaman tentang kebaikan serta memiliki kemampuan mengevaluasi secara tajam akan pentingnya berbuat kebaikan.

\section{b. Metode loving the good (mencintai kebaikan)}

Melakukan kebaikan dengan rasa cinta akan menjadikan anak konsisten dalam melakukan kebaikan, sebab cinta adalah unsure penting dalam pendidikan karakter.

\section{c. Metode desiring the good ( menginginkan kebaikan)}

Keinginan melakukan kebaikan lahir dati control internal yang berkaitan dengan adaya rasa bersalah, malu, dimana kontrol ini akan mencegah seseorang berperilaku buruk. 


\section{d. Metode acting the good ( mengerjakan kebaikan)}

Terbiasa melakukan kebaikan adalah inti dari pendidikan karakter. Kebiasaan diperoleh dari latihan dengan rasa senang melakukan sesuatu yang baik yang dicontohkan dengan perilaku model dari lingkungan yang kondusif.

\section{e. Metode keteladanan}

Dalam pendidikan karakter dibutuhkan keteladanan, sebab karakter merupakan perilaku bukan pengetahuan sehingga harus terinternalisasi kepada anak, maka harus diteladankan bukan diajarkan.

\section{f. Metode Penanaman atau Penegakan Disiplin}

Disiplin adalah metode yang ampuh dalam mendidik karakter. Banyak orag sukses karena disiplin. Dengan menanamkan disiplin, anak akan memiliki pendirian yang kokoh dalam melakukan kebaikan.

\section{g. Metode Pembiasaan}

Istilah lain dari pembiasaan adalah aplikasi atau pengulangan. Pembiasaan merupakan proses penanaman kebiasaan. Jika akan tumbuh dan berkembang dalam lingkungan yang baik, maka mereka akan terbiasa melakukan kebaikan. Metode ini penting dalam pembentukan karakter walaupun melalui proses yang lama dan terus menerus.

\section{h. Metode menciptakan Suasana yang kondusif}

Menciptakan lingkungan yang kondusif di keluarga, di sekolah dan di masyarakat merupakan upaya pembentukan karakter. Budaya baik yang dibangun di rumah, di sekolah dan di masyarakat akan membangun budaya berperilaku baik.

\section{i. Metode Integrasi dan Internalisasi}

Integrasi yang berarti bahwa nilai-nilai karakter itu tidak dapat lepas dari aspek lain dalam kehidupan dan internalisasi adalah pendidikan karakter itu harus mewarnai seluruh aspek kehidupan manusia. Nilai-nilai karakter yang diintegrasikan dan diinternalisasikan dalam seluruh kegiatan anak di rumah, di sekolah dan di masyarakat dapat dicapai melalui proses pembiasaan dalam kehidupan sehari-hari. 


\section{j. Metode Mengajarkan}

Mengajarkan nilai -nilai karakter adalah penting, supaya anak memiliki pemahaman konseptual tentang perilaku akan bermanfaat bagi anak untuk mengembangkan karakter pribadinya

\section{k. Metode Menentukan Prioritas}

Di dalam lembaga pendidikan harus menentukan salah satu prioritas berupa standar keilmuan, sehingga berhasil tidaknya harus dibuktikan melalui transparasi laporan perkembangan kemampuan akademik anak

\section{l. Metode Praksis Prioritas}

Adanya verifikasi tentang pendidikan karakter yang dituntutkan merupakan realisasi dari visi dari kebijakan lembaga pendidikan yang harus dipertanggungjawabkan di masyarakat, misalnya jika lembaga menentukan nilai demokrasi menjadi pilihan , maka harus bisa diverifikasi mellaui berbagai macam kebijakan, kepemimpinan yang demokrastis, setiap individu dalam lembaga memiliki hak yang sama.

\section{m. Metode Refleksi}

Refleksi adalah kemampuan sadar khas manusiawi yang menjadikan manusia mampu mnegatasi diri dan meningkatkan kualitas hidupnya. Proses pendidikan karakter adalah direfleksikan dan dievaluasi sehingga akan muncul adanya kemajuan. Jadi setelah anak memiliki kesempatan belajar dari pengalaman berbuat kebaikan, maka dia perlu merefleksikan pribdinya tentang nilai-nilai karakter yang dipraktekkannya.

\section{n. Metode Tobat}

Menurut al-Ghazali bahwa tobat merupakan metode tazkiyah annafs dalam membina moral . Dengan bertobat dari kesalahan yang pernah dilakukan, maka, seseorang akan menyadari kesalahannya untuk kembali ke jalan kebenaran, kesadaran hakikat hidup, melahirkan optimism, tertanamnya nilai kebaikan. seperti yang disebutkan dalam surat Al- baqarah ayar 222 bahawa Allah mencintai orang yang tobat dan mensucikan diri (Mutmainnah 2013, 23-35). 


\section{Peran Orang Tua dalam Pendidikan Agama Islam dalam Lingkungan Keluarga}

Penyebab kenakalan remaja salah satunya ada kurangnya pendidikan agama. Pendidikan bagi anak adalah pendidikan keteladanan yang baik pada mereka terutama sosialisasi nilai dan karakter dalam keluarga. Pendidikan awal yang diterima anak dalam keluarganya akan memberikan warna karakter seseorang dalam perjalanan kehidupan selanjutnya. Pendidikan agama dalam kehidupan sepenuhnya menjadi tanggung jawab orang tua, selain guru di sekolah, melainkan peran orang tua di rumah sangat penting. (Sukring 2013, 163).

Penelitian yang dilakukan oleh Penelitian Aviyah dan Farid (2014) regresi linear, kenakalan remaja (variable tergantung), religiusitas dan kontrol diri (variabel bebas) telah memenuhi uji normalitas sebaran dan uji linearitas hubungan, maka setelah dilakukan analisis ditemukan nilai $\mathrm{F}$ Regresi $=17,954$ dengan $\mathrm{p}=$ $0,00(p<0,01)$, hal ini berarti ada hubungan sangat signifikan antara religiusitas dan kontrol diri dengan kecenderungan kenakalan remaja. Hubungan antar variabel secara parsial, ditemukan $t$ antara religiusitas dengan kecenderungan kenakalan remaja $=-3,632$ dan $r$ parsial $=-0,346$, dengan $p=0,000(p<0,01)$, berarti ada hubungan sangat signifikan antara religiusitas dan kecenderungan kenakalan remaja. Artinya semakin tinggi religiusitas maka semakin rendah kecenderungan kenakalan remaja. Sumbangan efektif variabel religiusitas dan kontrol diri sebesar $27 \%$ ( $R$ square $=0,270$ ). Sumbangan efektif variabel religiusitas terhadap kecenderungan kenakalan remaja sebesar $16,13 \%$. Variabel kontrol diri terhadap kecenderungan kenakalan remaja sebesar 10,87\%.

Begitu penting peran pendidikan agama dalam mengurangi kenakalan remaja. Pendidikan agama adalah pendidikan yang memberikan pengetahuan, sikap dan membentuk sikap, kepribadian serta ketrampilan peserta didik dalam mengamalkan ajaran agamanya, yang dilaksanakan sekurang-kurangnya melalui mata pelajaran /kuliah pada semua jalur, jenjang dan jenis pendidikan . Pendidikan agama berfungsi membentuk manusia Indonesia yang beriman dan bertaqwa kepada Tuhan Yang maha Esa serta berakhlak 


\section{Efektifitas Peran Orang Tua Terhadap Keberhasilan Pendidikan ...}

mulia dan mampu menjaga kedamaian dan kerukunan, hubungan inter dan antar umat beragama (PP No . 55 Tahun 2007 Pasal 2 ayat 1 dalam Haedari, 2010: ix)

Pendidikan agama Islam pada dunia pendidikan merupakan modal dasar bagi seseorang untuk mendapatkan nilai-nilai ketuhanan, karena dalam pemdidikan agama Islam diberikan ajaran tentang muamalah, ibadah, dan syariah yang merupakan unsure ajaran agama (Sukring 2013, 162). Islam menganggap bahwa mendidik anak adalah jihad .Agar masyarakat memperhatikan urusan anak-anak, Islam menyatakan bahwa usaha orang tua dan para pendidik dalam membina dan mendidik anak serta memenuhi kebutuhan mereka adalah sama dengan ibadah dan berjuang di jalan Allah. Rasulullah bersabda bahwa satu hari bagi pemimpin yang bersikap adil, jauh lebih baik daripada ibadah selama tujuh puluh tahun.

Ide agama dalam diri anak sepenuhnya autoritas, maksudnya konsep keagamaan pada diri mereka dipengaruhi oleh faktor yang berasal dari luar diri mereka. mereka telah melihat dan mengikuti apa-apa yang dikerjakan dan diajarkan oleh orang dewasa dan orang tua mereka tentang sesuatau yangberhubungan dengan kemaslahatan agama, bagi mereka sangat mudah menerima ajaran dari orang dewasa walaupun belum sadari sepenuhnya manfaat ajaran tersebut (Mansur dalam Arif 2015, 88).

Anak merupakan amanah yang diberikan Allah kepada orang tua yang harus dipertanggungkawabkan di akhirat nanti. Sehingga Islam mengharuskan orang tua tua mendidika anak-anaknya beribadah kepada Allah sejak dini, sebagaimana sabda Rasullah SAW yang diriwayatkan oleh Ahmad, Abu Dawud dan Al-Hakim yang berbunyi "Perintahkan anak-anakmu untuk mengerjakan shalat pada saat berusia tujuh tahun dan pukullah mereka jika enggan melakukannya pada saat mereka berusia sepuluh tahun dan pisahkanlah tempat tidur mereka".

Jadi orang tua harus benar-benar memperhatikan pendidikan anak agar menjadi generasi Islami. Adapun peran orang tua yang dilakukan untuk memperoleh generasi Islami antara lain :

a. Mendorong anak membaca dan menghafal Alquran 
b. Mendorong untuk menghafal hadis-hadis nabi SAW

c. Mendorong anak menghayati ciptaan-ciptaan Allah SWT yang ada di lingkungan sekitar

d. Mendorong anak tujuh tahun untuk melaksanakan shalat pada waktunya. Dalam hal ini orang tua sebagai teladanan bagi anak dalam membiasakan shalat baik didalam rumah maupun di masjid.

e. Melatih anak bersikap sabar dan ridla apa yang telah terjadi dengan menunjukkan hikmah-hikmah yang bisa diperoleh bagi ornag yang sabar, baik dalam menghadapi ujian dan cobaab maupun dalam melaksanakan kewajiban sehari-hari

f. Mengajarkan kepada anak tentang pentingnya mencintai Allahdan Rasulullah di atas cinta yang lain. Sejak dini orang tua mengajarkan dan membiasakan karakter-karakter yang dicontohkan Rasulullah, seperti: sabar, qanaah, syukur, ikhlas, ridla, ikhtiar dan tawakkal kepada Allah.

g. Megajarkan kepada anak pentingnya penyucian hati dengan menghindari sifat tercela, seperti syirik, dusta, berani kepada orang tua, iri dengki, membenci dan berburuk sangka pada orang lain serta membicarakan orang lain.

h. Melatiha anak senang bersedekah kepada fakir miskin terutama dengan hartanya sendiri, meskipun sekedarnya. Yang penting mewujudkan sifat kedermawanan sejak dini pada diri anak. Orang tua juga perlu menambahkan motivasi bersedekah seperti dalam alquran dan hadis.

i. Membacakan kisah para nabi Allah dan kisah-kisah lain dalam Laquran kepada anak agar dapat mengambil ibrah (pelajaran) dari kisah-kisah tersebut.

j. Orang tua harus konsisten dalam menampakkan sikap dan perilaku positif kepada anak sehingga ia mendapatkan modelmodel karakter yang benar.

k. Menciptakan suasana keluarga yang penuh dengan kasih sayang dan saling menghormati antar anggota keluarga , baik yang muda terhadap yang dewasa maupun yang dewasa kepada ynag muda , sehingga anak merasa bangga dan tentram terhadap apa yang dilakukan kepada orang-orang dewasa. 
1. Menciptakn kondisi yang dapat melatih anak agar kecakapannya tumbuh dan berkembang baik kecakapan berpikir, emosi maupun spiritual sehinga sejak dini anak sudah melakukan proses pendidikan secara utuh.

m. Mengajak anak untuk terlibat langsung dalam diskusi dan berdialog dalam suasana demokratis dalam urusan-urusan penting keluarga yang merupakan bagian penting dalam diri anak.

n. Memperhatikan anak dengan menyiapkan berbagai program yang berisikan berbagai informasi pengetahuan yang sesuai dengan kemampuan berpikir dan usia anak untuk menumbuhkan kesadaran diri anak terhadap nilai-nilai Islam

o. Membantu anak dalam menerapkan nilai-nilai karakter Islam terutama dalam interaksi anak sehari-hari bersama temantemannya, baik di rumah, di sekolah maupun di tengah-tengah masyarakat (Marzuki 2015, 72-74).

Upaya pendidikan agama Islam yang dilakukan orang tua di atas adalah sebagai upaya pendidikan karakter Islami. Dengan memiliki karakter Islami anak-anak akan memiliki bekal dalam menyongsong masa depannya. Sebab karakter Islami adalah karakter kuat yang mampu membuat manusia tetap bertahan di kala mengalami problem atau kesulitan hidup. Dengan karakter ini manusia bisa meraih kesuksesan di dunia dan akhirat.

\section{Simpulan}

Kenakalan remaja dan anak yang semakin marak ini akan mengalami penurunan bila orang tua dalam keluarga benar-benar menjalankan peran dan fungsinya. Orang tua adalah pendidik pertama dan utama dalam membentuk moral atau akhlak anak. Keteladanan sebagai metode dalam dalam memberikan pendidikan agama Islam adalah metode paling tepat dalam membentuk akhlak anak. Sebab, dari keteladanan anak tidak hanya mendengar dan melihat saja tapi mempraktikan konsep-konsep, nilai-nilai luhur Islam sehingga muncul generasi Islam yang sholih dan beradab. 


\section{Daftar Pustaka}

Arif, Mansur dkk. 2015. Antologi pendidikan Anak Usia Dini dan pendidikan Dasar Islam. Yogyakarta: Pascasarjana UIN Sunan Kalijaga

Aviyah, Evi \& Farid, Muhammad. 2014. "Religiusitas, Kontrol Diri dan Kenakalan Remaja”. Persona: Jurnal Psikologi Indonesia.

Badan Keluarga Berencana Nasional. 2007. Kurikulum dan ModulPelatihan Pemberian Informasi Kesehatan Reproduksi RemajaOleh Pendidik Sebaya. Jakarta: Direktorat Remaja dan Perlindungan Hak - Hak Reproduksi

Fatimah, Siti \& Umuri, M. Thowil. 2014. "Faktor-faktor Penyebab Kenakalan Remaja di desa Kemadang Kec. Tanjungsari Kab. Gunung Kidul”. Jurnal Citizenship. Vol 4 No 1

Haedari, Amin. 2010. Pendidikan Agama di Indonesia : Gagasan dan Realitas. Jakarta: Puslitbang Pendidikan Agama dan Keagamaan Badan Litbang dan Diklat Kementrian Agama RI Gd. Bayt Al-Qur'an Museum Istiqlal Taman Mini Indonesia Indah

Marzuki. 2015. Pendidikan Karakter Islam. Jakartta: Penerbit Amzah Mutmainnah, Robingatul. 2013. Metode pendidikan Karakter dalam Pendidikan Islam. Yogyakarta: Idea Press

Nata, Abuddin. 2016. Pendidikan dalam Perspektif Alquran. Jakarta: Prenadamedia Group

Sukring. 2013. Pendidikan Agama Islam. Yogyakarta: Kaukaba Pressindo

Sri Lestari. 2012. Psikologi Keluarga: Penanaman Nilai dan Penanganan Konflik dalam Keluarga. Jakarta: Penerbit kencana Prenada Media Group 